\title{
Article \\ Removal of Organic UV Filters Using Enzymes in Spent Mushroom Composts from Fungicultures
}

\author{
Chu-Wen Yang, Ping-Hsun Tu, Wen-Yi Tso and Bea-Ven Chang *
}

Citation: Yang, C.-W.; Tu, P.-H.; Tso, W.-Y.; Chang, B.-V. Removal of Organic UV Filters Using Enzymes in Spent Mushroom Composts from Fungicultures. Appl. Sci. 2021, 11, 3932. https://doi.org/10.3390/ app11093932

Academic Editor: Nídia Dana Lourenço

Received: 18 March 2021

Accepted: 24 April 2021

Published: 26 April 2021

Publisher's Note: MDPI stays neutral with regard to jurisdictional claims in published maps and institutional affiliations.

Copyright: (c) 2021 by the authors. Licensee MDPI, Basel, Switzerland. This article is an open access article distributed under the terms and conditions of the Creative Commons Attribution (CC BY) license (https:/ / creativecommons.org/licenses/by/ $4.0 /)$.
Department of Microbiology, Soochow University, Taipei 11102, Taiwan; ycw6861@scu.edu.tw (C.-W.Y.); jack840623@gmail.com (P.-H.T.); vicky.tso73@gmail.com (W.-Y.T.)

* Correspondence: bvchang@scu.edu.tw

\begin{abstract}
Organic UV filters in sunscreen products are released to aquatic ecosystems through human recreational activities and urban wastewater treatment plant effluents. The biodegradation of three organic UV filters, 2-ethylhexyl salicylate (EHS), homosalate (HMS) and ethylhexyl methoxycinnamate (EHMC), which cannot be effectively removed by conventional wastewater treatment plants, was investigated in this study. Spent mushroom compost (SMC), a waste product of the mushroom industry, which contains white-rot fungus extracellular enzymes, was tested for its ability to remove the three organic UV filters. The results of batch experiments revealed that the SMC enzyme extract of Pleurotus djamor exhibited the highest ability for EHS and HMS removal. The results of bioreactor experiments indicated that direct application of SMCs may be a feasible solution to remove EHS and HMS from urban wastewater. The application of SMCs for the removal of organic UV filters can be developed into a green and sustainable technology.
\end{abstract}

Keywords: sunscreen; laccases; wastewater; mycoremediation

\section{Introduction}

Organic UV filters are major components of sunscreen products. They can absorb solar UV radiation to protect humans from acute (sunburn, photoaging) and chronic (skin cancer) damage [1]. Organic UV filters are released into aquatic ecosystems through human recreational activities and urban wastewater effluents [2]. For instance, two organic UV filters (homosalate (HMS) and ethylhexyl methoxycinnamate (EHMC)) were identified in the Nanjing Qinhuai River system (an urban river system) [3]. EHMC and 2-ethylhexyl salicylate (EHS) were identified in samples from eleven sites among three rivers, five sewage treatment plants and four wastewater treatment plants located in different parts of South Korea [4]. A study by da Silva et al. (2015) indicated that EHMC and EHS were present in samples from six water treatment plants in cities in Southeast Brazil [5]. A study by Kameda et al. (2011) indicated that EHMC and HMS were present in surface waters and sediments in Japanese rivers and lakes. [6]. EHMC and HMS were also identified in samples from estuaries in Port Phillip Bay, Victoria, Australia [7] and Chesapeake Bay, USA [8]. These results indicated that three organic UV filters (EHS, HMS and EHMC) widely occur in urban wastewater, freshwater rivers and lakes and cannot be effectively removed by conventional wastewater treatment plants.

In the past, studies of organic UV filters mainly focused on the distributions of organic UV filters in the environment and sewage, as well as the bioaccumulation and toxicity of organic UV filters to users (humans) and organisms in environments [9-11]. An increasing number of experimental studies indicated that several organic UV filters (such as benzophenone-3, 3-benzylidene camphor, 3-(4-methyl-benzylidene) camphor, 2-ethylhexyl 4-methoxy cinnamate, homosalate (HMS), 2-ethylhexyl 4-dimethylaminobenzoate and 4-aminobenzoic acid) might have endocrine disruptive effects [9]. Many in vivo and in vitro studies of organic UV filters have revealed a wide variety of adverse effects on 
the exposed organisms, such as coral bleaching, which has received considerable attention $[10,11]$. Laboratory studies show that UV filters alter the development of the brain and liver in zebrafish. High levels of UV filters led to decreased egg production and significantly fewer hatchings in Japanese rice fish [10]. Moreover, potential endocrine, neurologic, neoplastic and developmental toxicities of organic UV filters may be detrimental to a vast array of aquatic and marine organisms [11-13]. Some organic UV filters are proven to accumulate in various kinds of aquatic organisms and, as a consequence, have adverse effects on organisms in the food web including humans. The removal of organic UV filters in the environment has become an important issue. However, little is known about the biodegradation and biotransformation of organic UV filters.

Biodegradation and biotransformation are techniques that exploit the ability of microorganisms to break down or transform pollutants [14]. Mycoremediation, employing extracellular enzymes of white-rot fungi for the removal of organic pollutants, is a cost-effective, eco-friendly and efficacious method [15-18]. The identification, study and implementation of laccase-mediated processes to eliminate pollutants from contaminated environments is an intensive research area of mycoremediation $[19,20]$. Laccases belong to the enzyme family of multicopper oxidases, which are classified as benzenediol oxygen reductases (EC 1.10.3.2) and are also known as urushiol oxidases and p-diphenol oxidases [21]. They are versatile enzymes with low substrate specificity and high capability to oxidize a large number of phenolic and nonphenolic molecules [22]. Adsorption is another strategy of mycoremediation. For example, the removal of heavy metal pollutants can be achieved by adsorption $[23,24]$.

Spent mushroom compost (SMC), a waste product of the mushroom industry, contains white-rot fungus extracellular enzymes that can be used to degrade many organic pollutants such as acetaminophen, sulfonamides and tetrabromobisphenol-A [25-27]. SMC is mainly composed of $95 \%$ natural wood chips and other ingredients such as rice bran, corn flour and wheat flour. Therefore, in addition to the use of extracellular enzymes to decompose organic pollutants, SMCs can also be used to remove organic pollutants by adsorption [25]. The application of SMCs for organic UV filter removal is a mycoremediation-based green and sustainable technology.

The aim of this study is to test the removal efficiency of three organic UV filters (EHS, HMS and EHMC) using SMCs of four different mushrooms (Pleurotus eryngii, Pleurotus djamor, Pleurotus ostreatus and Auricularia polytricha). The effects of enzyme extracts of the four SMCs were investigated by batch experiments. Bioreactor experiments were conducted to simulate the efficiency of UV filter removal in reverse osmosis (RO) filtration water and wastewater (wastewater treatment plant effluent) by direct use of SMCs.

\section{Materials and Methods}

\subsection{Chemicals}

Chemicals, solvents and the three UV filters, EHMC, HMS, EHS (analytical grade, 99.0\% purity) were purchased from Sigma-Aldrich (Merck/Millipore Sigma, St. Louis, $\mathrm{MO}$, USA). The chemical structure formulas of the three target compounds are shown in Figure 1B.

\subsection{Wastewater Sampling and Spent Mushroom Compost}

Wastewater (effluent after secondary treatment) was sampled from the Dihus domestic sewage treatment plant, Taipei City, Taiwan. SMCs of four mushrooms (P. eryngii, P. djamor, P. ostreatus and A. polytricha) were obtained from a mushroom cultivation farm in Nantou, Taiwan (Figure 1A). 


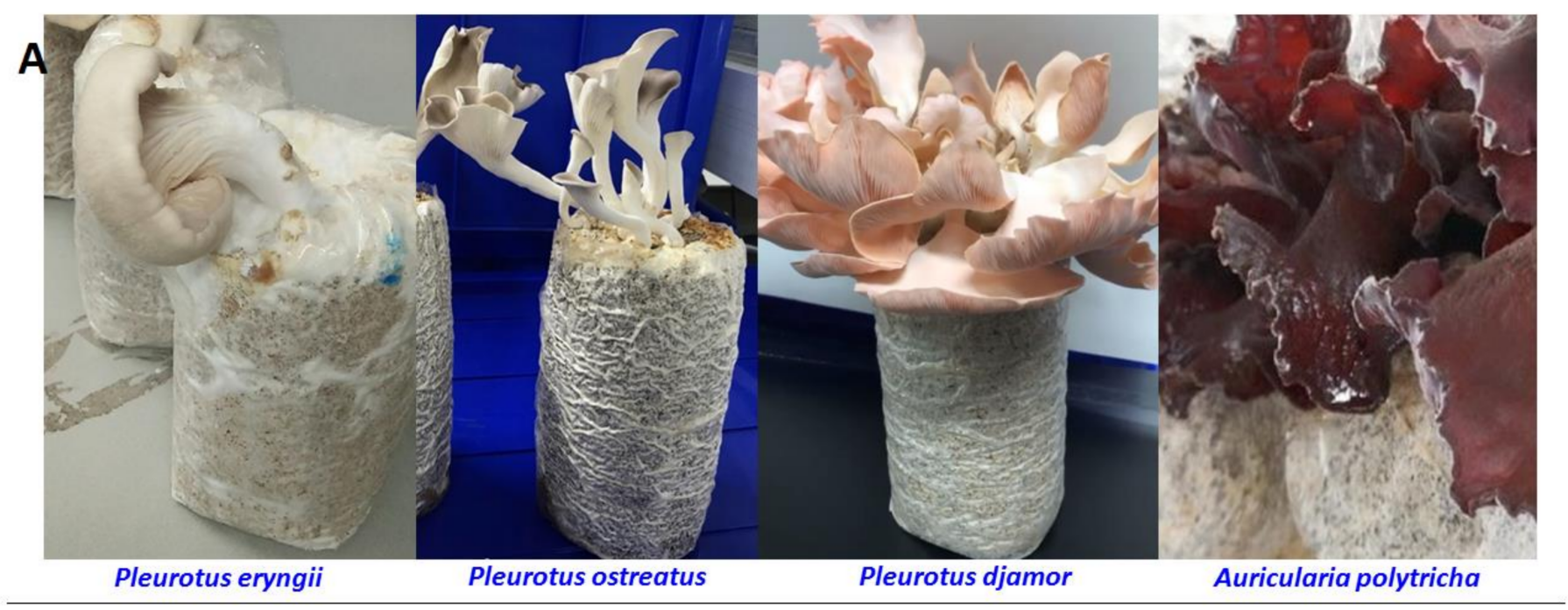

B<smiles>CCCCC(CC)COC(=O)/C=C/c1ccc(OC)cc1</smiles>

ethylhexyl methoxycinnamate (EHMC)<smiles>CCCCC(CC)COC(=O)c1ccccc1O</smiles>

Ethylhexyl salicylate (EHS)<smiles>CC1CC(OC(=O)c2ccccc2O)CC(C)(C)C1</smiles>

Figure 1. Spent mushroom composts (SMCs) of four mushrooms (A). Chemical structure formulas of the three organic UV filters used in this study (B).

\subsection{Analysis of Remaining UV Filters in Experimental Samples}

For batch experiments, a $1 \mathrm{~mL}$ sample (reaction mixture) was filtered by a $0.22 \mu \mathrm{m}$ filter and applied to HPLC analysis. For bioreactor experiments, $0.5 \mathrm{~g}$ of SMC was mixed with $0.5 \mathrm{~mL}$ of methanol. The mixture was vortexed $10 \mathrm{~s}$ and centrifuged at 12,000 rpm for $10 \mathrm{~min}$. The liquid phase was collected and filtered by a $0.22 \mu \mathrm{m}$ filter and applied to HPLC analysis. UV filters were analyzed using an Agilent 1260 HPLC equipped with a $4.6 \times 250 \mathrm{~mm}$ column (Zorbax Eclipse Plus C18, Agilent) and monitored by a photodiode array detector at $311 \mathrm{~nm}$ (Agilent Technologies, Inc., Santa Clara, CA, USA). The solvents delivered by the analytical pump were acetonitrile (A) and water (containing $0.1 \%$ formic acid) (B). Samples were eluted at $1 \mathrm{~mL} / \mathrm{min}$ with a gradient starting from $70 / 30(\mathrm{~A} / \mathrm{B})$ for $13 \mathrm{~min}$ and then from 80/20 (A/B) for 13-30 min. The recovery percentages for EHMC, HMS and EHS were 95.3, 95.6 and 94.3, respectively. The detection limits for EHMC, HMS and EHS were $0.01,0.01$ and $0.01 \mathrm{mg} / \mathrm{L}$, respectively. The remaining percentages of organic UV filters were calculated using the formula: [\%] = (residue UV filter concentration/initial UV filter concentration) $\times 100$.

\subsection{Batch Experiments}

The SMC enzyme extracts were prepared as described previously [22]. Briefly, SMCs containing mushroom mycelium were broken into fragments. A $120 \mathrm{~g}$ amount of SMC fragments and $400 \mathrm{~mL}$ of sodium acetate buffer ( $\mathrm{pH}$ 5.0) were mixed in a $1000 \mathrm{~mL}$ flask and incubated in a $130 \mathrm{rpm}$ shaker at $25^{\circ} \mathrm{C}$ for $3 \mathrm{~h}$. The mixtures were centrifuged at $8000 \mathrm{rpm}$ for $15 \mathrm{~min}$. The supernatant was collected and filtered by a $0.22 \mu \mathrm{m}$ filter and referred to as SMC enzyme extract.

Batch experiments were performed using $125 \mathrm{~mL}$ flask bottles containing $50 \mathrm{~mL}$ of SMC extract and $2 \mathrm{mg} / \mathrm{L}$ UV filters. Reaction mixtures were incubated in a shaker (120 rpm) at $25{ }^{\circ} \mathrm{C}$ in the dark. Samples were taken periodically to analyze the residual UV filter 
concentrations. A single UV filter was used in each test at a time. Each experiment was performed in triplicates.

Laccase activity was measured in reaction mixtures of $0.5 \mathrm{~mL}$ of enzyme, $0.25 \mathrm{~mL}$ of $100 \mathrm{mM}$ glycine buffer ( $\mathrm{pH} 3.0)$ and $0.25 \mathrm{~mL}$ of $5 \mathrm{mM}$ ABTS. After reaction under $25^{\circ} \mathrm{C}$ for $5 \mathrm{~min}$, enzyme activities were measured by a spectrophotometer using $420 \mathrm{~nm}$. Laccase activity was computed by the following formula: laccase activity (units/L) = $(\Delta A b s / \Delta t \varepsilon l) \times($ total assay volume/enzyme sample volume), where $\Delta t$ is the incubation time (min), $\triangle A b s$ is the change in absorbance, $\varepsilon$ is the extinction coefficient of the substrates $\left(\varepsilon_{420}=36 \mathrm{mM}^{-1} \mathrm{~cm}^{-1}\right.$ for ABTS $)$ and $l$ is the cuvette diameter $(1 \mathrm{~cm})$.

\subsection{GC-MS Analysis of Intermediates of Biodegradation and Biotransformation}

Biodegradation and biotransformation intermediates of organic UV filters by the SMC enzyme extracts were evaporated to near dryness under a gentle stream of nitrogen and analyzed by a $6890 \mathrm{~N}$ gas chromatograph (Agilent Technologies, Santa Clara, CA, USA) equipped with a single quadrupole mass spectrometer. A ZB-5 fused-silica capillary column ( $5 \%$ phenyl-95\% dimethylpolysiloxane, $15 \mathrm{~m} \times 0.25 \mathrm{~mm}$ i.d., $0.25 \mu \mathrm{m}$ film thickness, Zebron ZB-5 Capillary GC) was used. The carrier gas in the constant flow mode (He, purity $99.9995 \%$ ) at $1.1 \mathrm{~mL} / \mathrm{min}$ was used. The split/splitless injection port in split mode at $280^{\circ} \mathrm{C}$ was used. The chromatographic oven was programmed as follows: $50^{\circ} \mathrm{C}$, hold for $1 \mathrm{~min}$, increase of $10^{\circ} \mathrm{C} / \mathrm{min}$ up to $200^{\circ} \mathrm{C}$, increase of $200^{\circ} \mathrm{C} / \mathrm{min}$ up to $290^{\circ} \mathrm{C}$ and hold for $8 \mathrm{~min}$. The mass spectrometer was operated in the electron impact (EI) positive mode $(70 \mathrm{eV})$. The MS transfer line temperature was $280^{\circ} \mathrm{C}$, the MS ion source temperature was $230^{\circ} \mathrm{C}$, and the MS quadrupole temperature was $150^{\circ} \mathrm{C}$.

\subsection{Adsorption Experiments}

A $125 \mathrm{~mL}$ flask containing $10 \mathrm{~g}$ of SMC, $50 \mathrm{~mL}$ of sterile water and each UV filter at different concentrations $(2,10,20,50,100 \mathrm{mg} / \mathrm{L})$ were used to conduct adsorption experiments. The samples were incubated on a shaker $(120 \mathrm{rpm})$ at $25^{\circ} \mathrm{C}$ in the dark for $24 \mathrm{~h}$. The suspensions were centrifuged $(5870 \times g, 30 \mathrm{~min})$, and the supernatants were filtered by $0.22 \mu \mathrm{m}$ filters. The residual organic UV filter was determined by HPLC. Each experiment was performed in triplicates. The adsorption isotherm of organic UV filter was fit with linear regression, i.e., $S=K_{d} C$, where $K_{d}$ is the adsorption constant, $S$ is the concentration of UV filter in the solid phase and $C$ is the concentration of UV filter in the aqueous phase.

\subsection{Bioreactor Experiments}

The settings of the bioreactor experiments are shown in Figure 2. Plastic filter funnels with a volume of $500 \mathrm{~mL}$ were used as reactors. The reactors were treated with $\mathrm{RO}$ water that was circulated through the reactor for $24 \mathrm{~h}$. After the steady state was reached, the reactors with flow rates of either $500 \mathrm{~mL} / 2 \mathrm{~h}$ or $500 \mathrm{~mL} / 30 \mathrm{~min}$ were continuously fed either RO water or wastewater containing $20 \mathrm{mg} / \mathrm{L}$ UV filter flowed through $200 \mathrm{~g}$ of SMCs. The bioreactor was maintained at room temperature $\left(25^{\circ} \mathrm{C}\right)$ by air conditioners. The remaining (\%) UV filters in the solid phase of SMCs were measured periodically. 


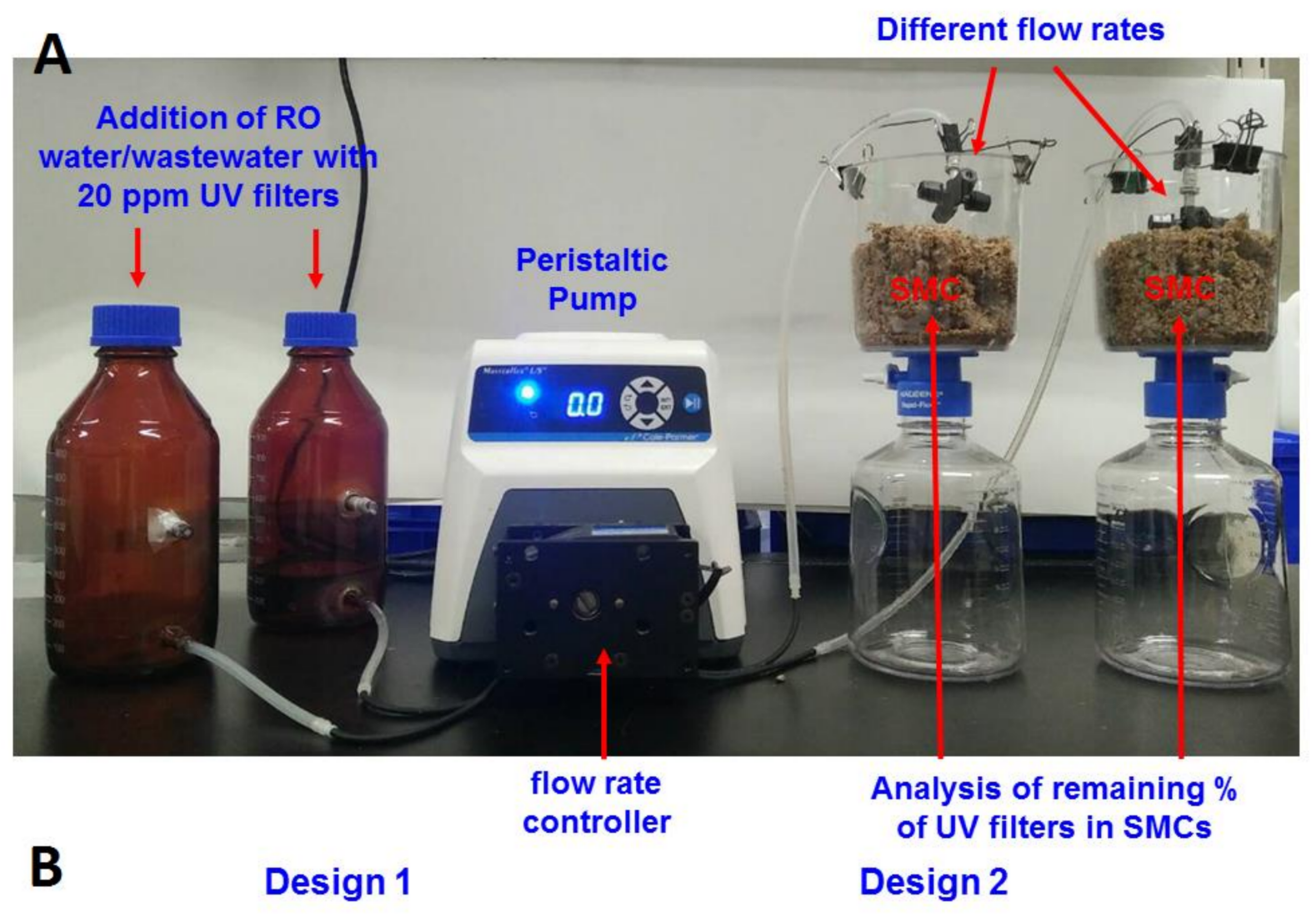

$500 \mathrm{~mL}$ RO water/wastewater Flow rates: $\mathbf{5 0 0} \mathrm{mL} / \mathbf{2} \mathrm{h}$

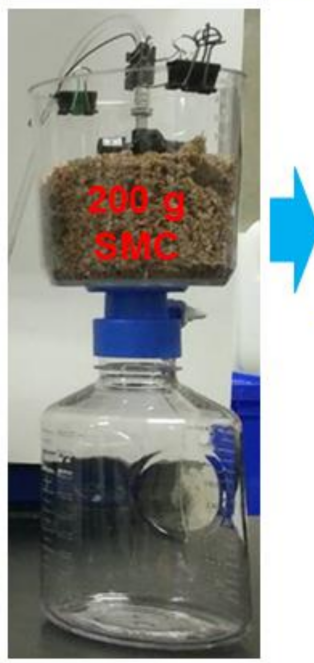

Analysis of remaining UV filters in SMCs after $\mathbf{5 0 0} \mathbf{~ m L}$ RO water/wastewater flow out

Figure 2. Experimental settings of bioreactor experiments. (A) A $500 \mathrm{~mL}$ volume of $\mathrm{RO}$ water/wastewater with a $20 \mathrm{ppm}$ UV filter was fed to the bioreactors using a peristaltic pump as a flow rate controller. (B) Two flow rates: $500 \mathrm{~mL} / 2 \mathrm{~h}$ and $500 \mathrm{~mL} / 30 \mathrm{~min}$ were used in this study. The remaining (\%) of each UV filter in SMCs was determined after $500 \mathrm{~mL}$ of RO water/wastewater flow through SMCs. SMC: spent mushroom compost. 


\section{Results}

\subsection{Performances of UV Filter Removal Using Enzyme Extracts of SMCs}

As shown in Figure 3, the order of the UV filter removal rates of enzyme extracts from the four SMCs was P. djamor $>$ P. ostreatus $>$ P. eryngii $>$ A. polytricha. P. djamor exhibited the highest efficiency of UV filter removal. The order of the UV filter removal efficiency was EHMC > EHS > HMS. The enzymes of A. polytricha were ineffective in EHS and HMS degradation. In contrast, EHMC can be removed by all of the four SMC enzyme extracts very fast. These results indicate that the enzyme associated with EHS and HMS removal is absent or at a very low level in the SMC enzyme extracts of $A$. polytricha. In contrast, the enzymes involved in the EHMC removal were present in all SMCs.

The laccase activities and $\mathrm{pH}$ values of the SMC enzyme extracts at the start and end of the batch experiments are shown in Figure 4. The laccase activities in the enzyme extracts from A. polytricha were much lower than those of the other three fungi (Figure $4 \mathrm{~A}$ ). The $\mathrm{pH}$ values of all SMC enzyme extracts increased after the batch experiments (Figure 4B).
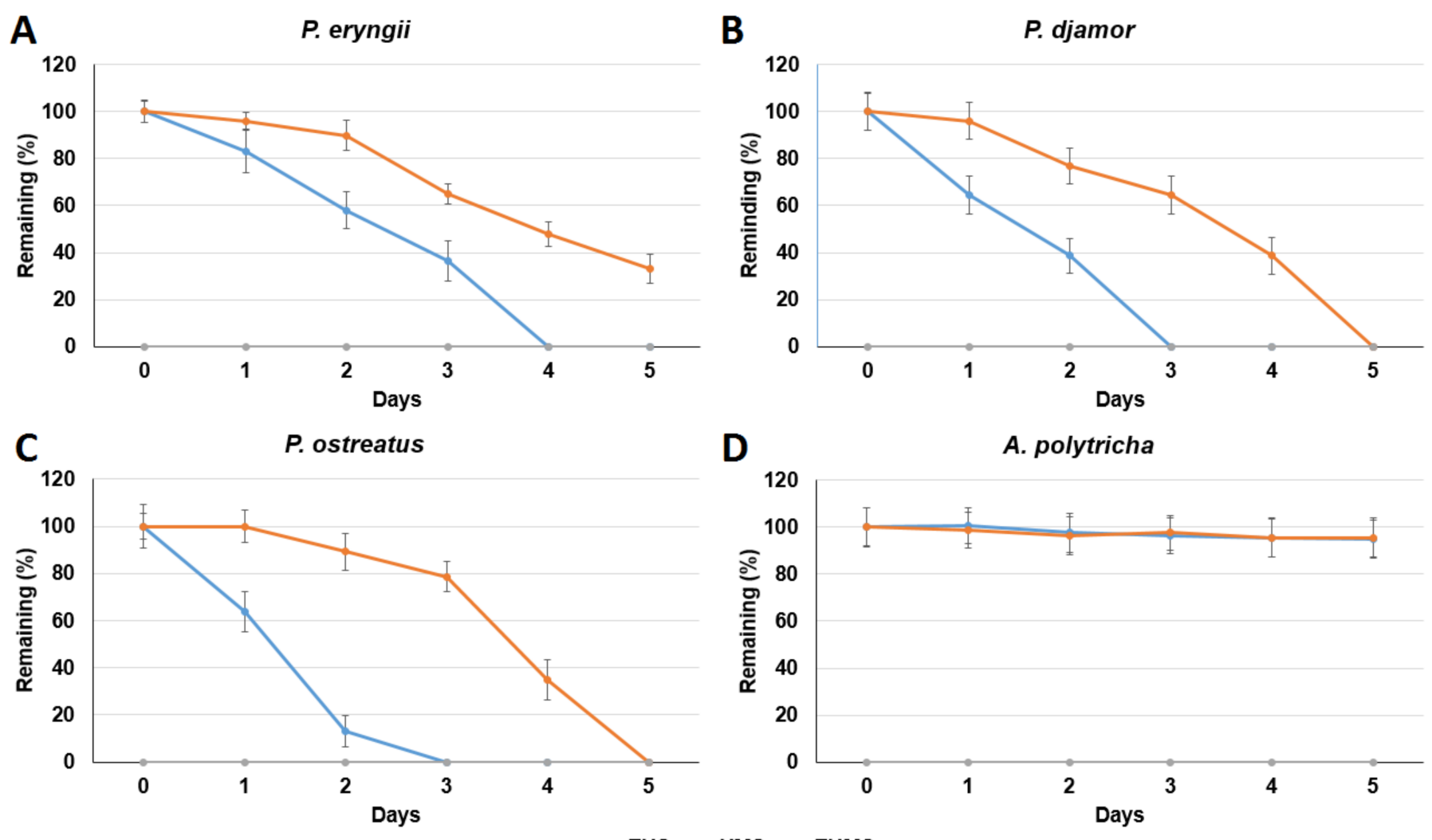

Figure 3. Removal of three UV filters (2 ppm) by enzyme extracts of the spent mushroom compost of four mushrooms ((A) P. eryngii, (B) P. djamor, (C) P. ostreatus and (D) A. polytricha). Data from triplicate experiments are presented as the mean \pm SE. EHMC: ethylhexyl methoxycinnamate, EHS: 2-ethylhexyl salicylate, HMS: homosalate. 


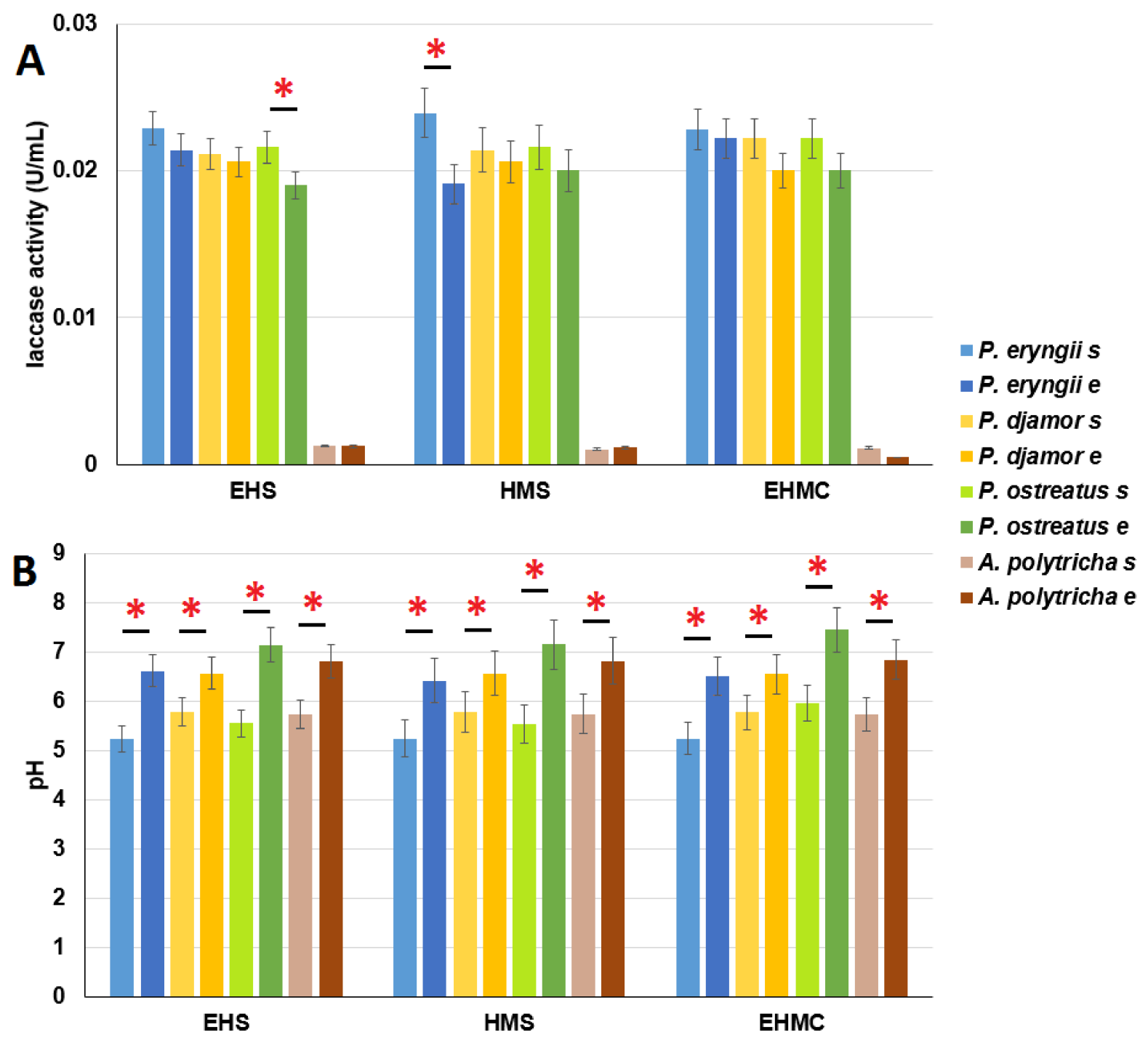

Figure 4. (A) Laccase activity and (B) $\mathrm{pH}$ values of the enzyme extracts before and after batch experiments. Data from triplicate experiments are presented as the mean \pm SE. s: start of experiments, e: end of experiments. EHMC: ethylhexyl methoxycinnamate, EHS: 2-ethylhexyl salicylate, HMS: homosalate. Red stars indicate the $p$ values of $t$ tests $<0.05$.

\subsection{The Intermediate Products of Removal of EHMC, EHS and HMS}

To further understand the removal of EHMC, EHS and HMS by SMC enzyme extracts, intermediates in batch experiments of P. djamor were analyzed. As shown in Figure 5A, HMS was converted to m-hemipic anhydride, 3,4-dimethoxy benzenemethanol and 3,4dimethoxy-benzaldehyde and finally was converted to benzoic acid. EHS was converted to 3,4-dimethoxy-benzaldehyde. 3,4-Dimethoxy-benzaldehyde was finally converted to benzoic acid (Figure 5B). EHMC was converted to its isomer (2-propenoic acid, 3-[4methoxyphenyl]-, 2-ethylhexyl ester) (Figure 5C).

\subsection{Determination of UV Filter Adsorption by SMCs}

It is time-consuming and difficult to produce large amounts of enzyme extracts of SMCs for wastewater treatment. Therefore, the direct application of SMCs for UV filter removal was tested. As shown in Figure 6, the ranges of the adsorption coefficients of EHS and HMS were 30.9 to 10.1. The range of the adsorption coefficients of EHMC was 18.3 to 11.3. These results suggested that SMCs exhibit higher adsorption ability for EHS and HMS than EHMC. 
A

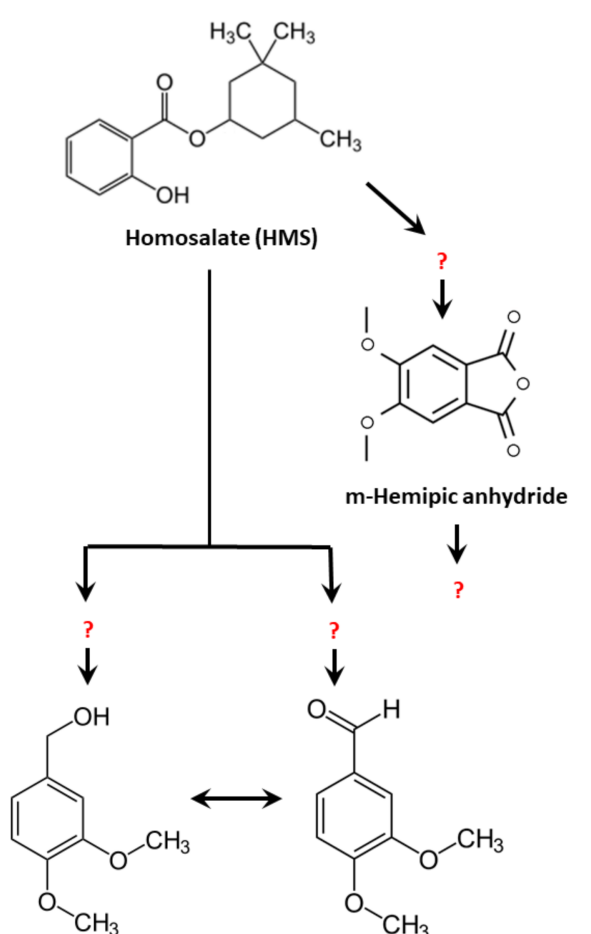

3,4-dimethoxy-Benzenemethanol 3,4-dimethoxy-Benzaldehyde

$\downarrow$

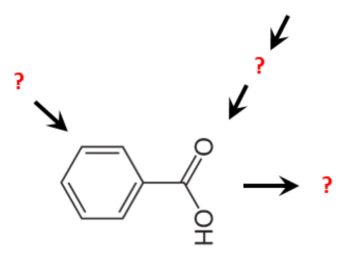

Benzoic_acid
B<smiles>CCCCC(CC)COC(=O)c1ccccc1O</smiles><smiles>COc1ccc(CO)cc1OC</smiles>

3,4-dimethoxy-Benzenemethanol 3,4-dimethoxy-Benzaldehyde

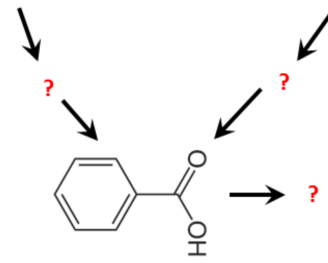

Benzoic_acid

C<smiles>CCCCC(CC)COC(=O)/C=C/c1ccc(OC)cc1</smiles>

Octyl 4-methoxycinnamate (EHMC)

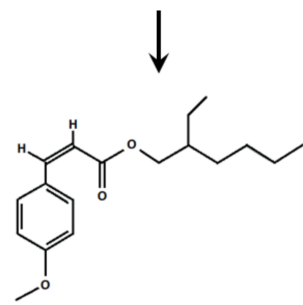

2-Propenoic acid, 3-(4-methoxyphenyl)-, 2-ethylhexyl ester

Figure 5. Intermediates of the biodegradation and biotransformation of homosalate (A), 2-ethylhexyl salicylate (B) and ethylhexyl methoxycinnamate $(\mathbf{C})$ by enzyme extracts from the spent mushroom compost of Pleurotus djamor. Question marks indicate unidentified intermediates. 
A

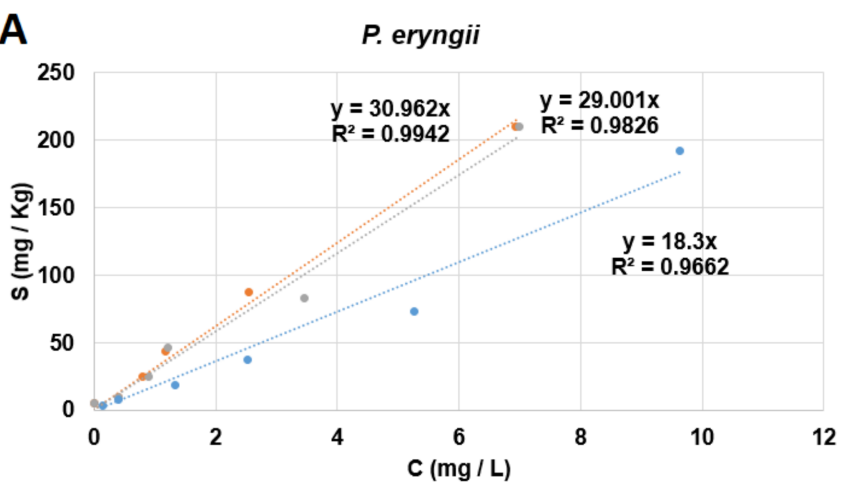

C

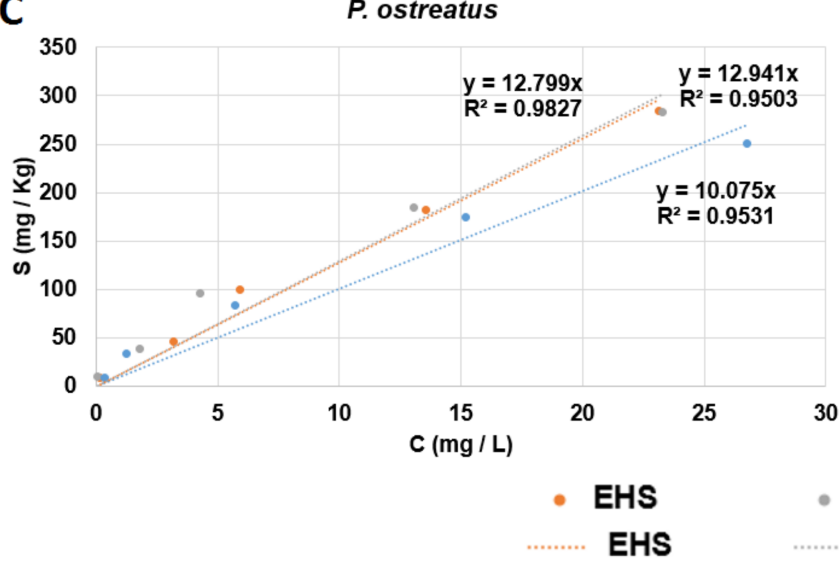

B

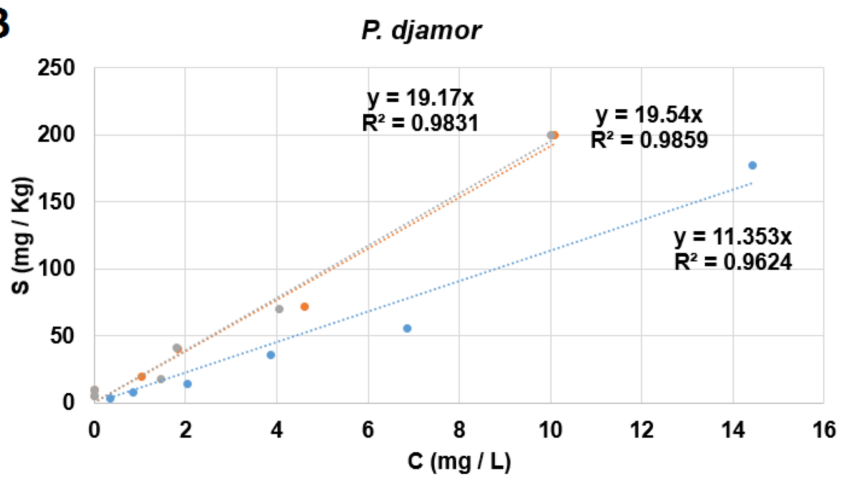

D
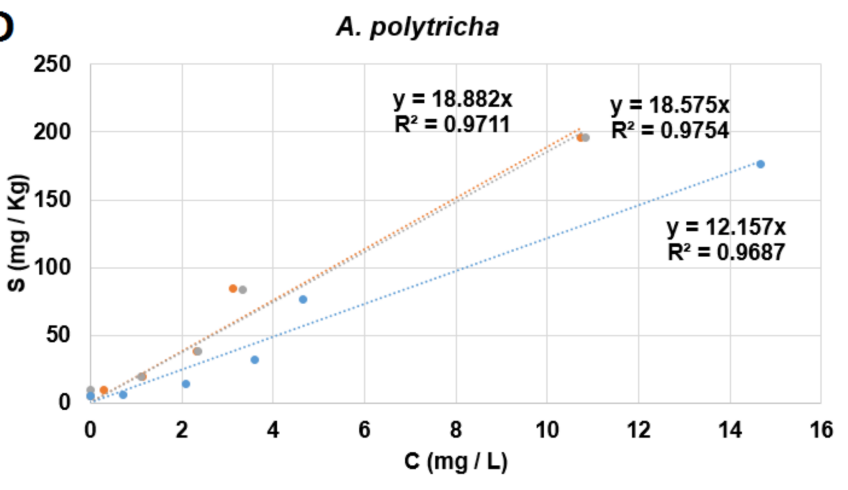

\section{HMS}

HMS
- EHMC

EHMC

Figure 6. Linear adsorption isotherm of the spent mushroom compost of four mushrooms ((A) P. eryngii, (B) P. djamor, (C) P. ostreatus and (D) A. polytricha). The label of the $y$-axis, S, is the concentration of the substrates (EHMC: ethylhexyl methoxycinnamate, EHS: 2-ethylhexyl salicylate, HMS: homosalate) in the solid phase. The label of the $x$-axis, C, is the concentration of the substrates (EHMC, EHS and HMS) in the aqueous phase.

\subsection{Comparison of UV Filter Removal in RO Water and Effluent Using SMCs}

To simulate the removal of UV filters by SMCs, bioreactor experiments were conducted. The remaining (\%) UV filters in SMCs were determined and are shown in Figures 7 and 8. A slow flow rate $(500 \mathrm{~mL} / 2 \mathrm{~h})$ led to more UV filter adsorption on SMCs. The absorbed UV filters were removed gradually by enzymes in the SMCs (Figures 7 and 8). The $\mathrm{pH}$ values of all SMCs increased after the bioreactor experiments (Figures 9 and 10). The SMC of A. polytricha exhibited very low laccase activity (Figure 10E,F) and cannot be used to remove EHS and HMS (Figure 8E-H). Although wastewater contains many impurities that may have some inhibitory effects on laccases (Figure $9 \mathrm{~A}, \mathrm{~B}, \mathrm{E}, \mathrm{F}$ and Figure $10 \mathrm{~A}, \mathrm{~B}, \mathrm{E}, \mathrm{F}$ ), the degradation efficiency of UV filters in wastewater was comparable with the degradation efficiency of UV filters in RO water (Figures 7 and 8). 


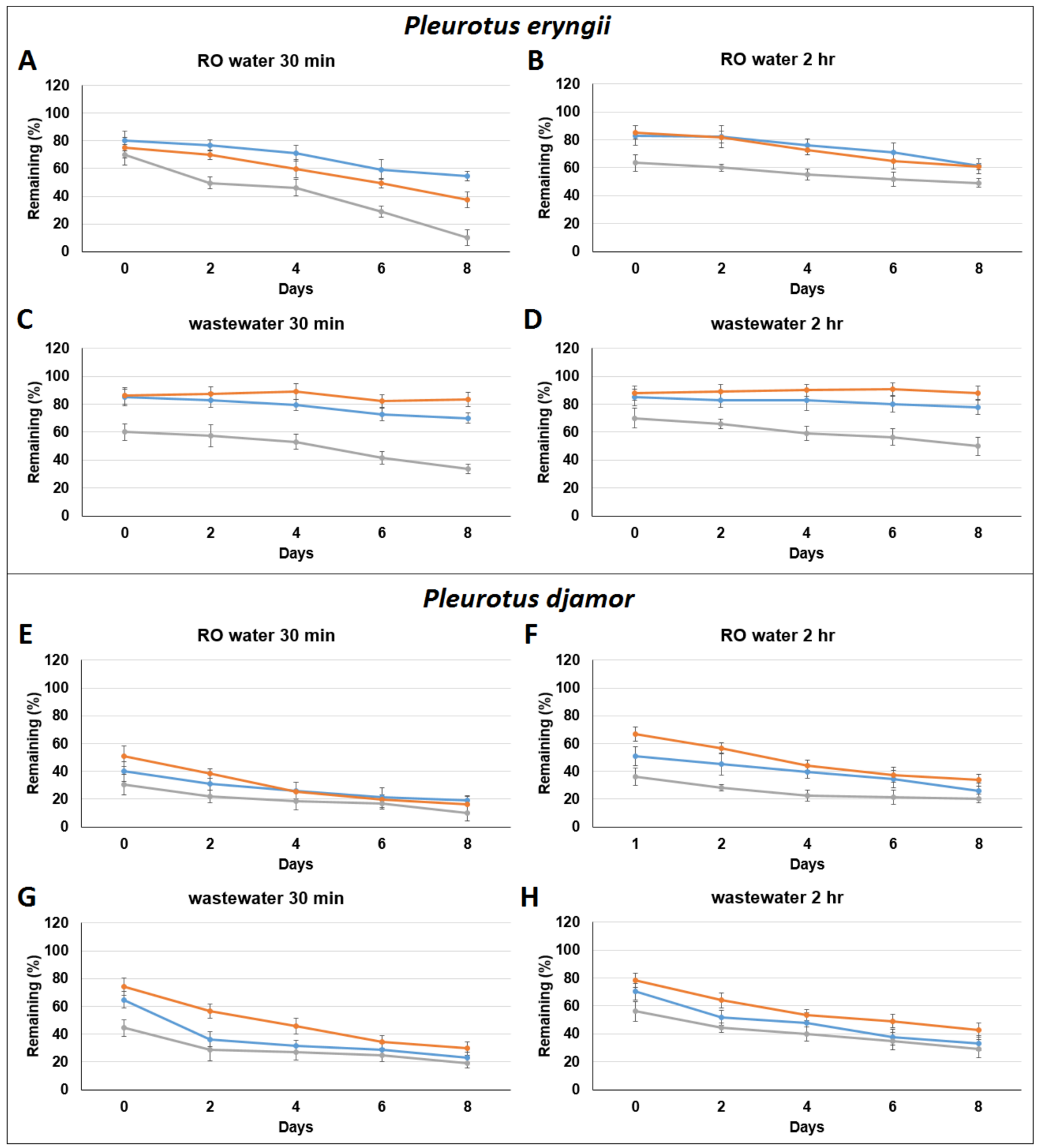

EHS $\multimap$ HMS

EHMC

Figure 7. Bioreactor experiments simulating UV filter $(20 \mathrm{ppm})$ removal in reverse osmosis (RO) filtration water $(\mathbf{A}, \mathbf{B}, \mathbf{E}, \mathbf{F})$ and wastewater $(\mathbf{C}, \mathbf{D}, \mathbf{G}, \mathbf{H})$ using the spent mushroom compost of two mushrooms (Pleurotus eryngii (A-D) and Pleurotus djamor $(\mathbf{E}-\mathbf{H})$ ). Data from triplicate experiments are presented as the mean \pm SE. EHMC: ethylhexyl methoxycinnamate, EHS: 2-ethylhexyl salicylate, HMS: homosalate. 


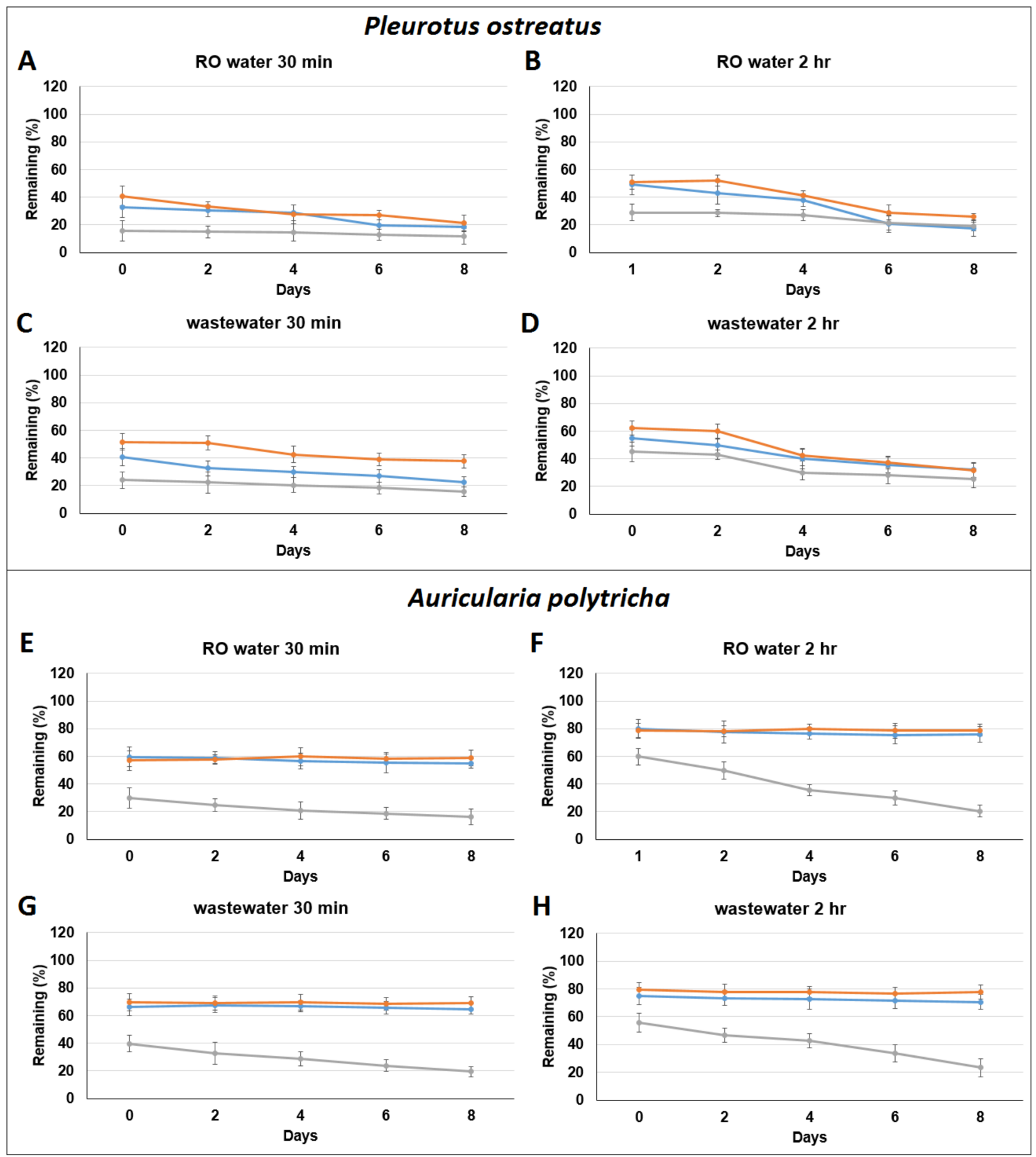

- EHS $\rightarrow$ HMS $\rightarrow$ EHMC

Figure 8. Bioreactor experiments simulating UV filter (20 ppm) removal in reverse osmosis (RO) filtration (A,B,E,F) and wastewater $(\mathbf{C}, \mathbf{D}, \mathbf{G}, \mathbf{H})$ using the spent mushroom compost of two mushrooms (Pleurotus ostreatus (A-D) and Auricularia polytricha $(\mathbf{E}-\mathbf{H}))$. Data from triplicate experiments are presented as the mean \pm SE. EHMC: ethylhexyl methoxycinnamate, EHS: 2-ethylhexyl salicylate, HMS: homosalate. 
A

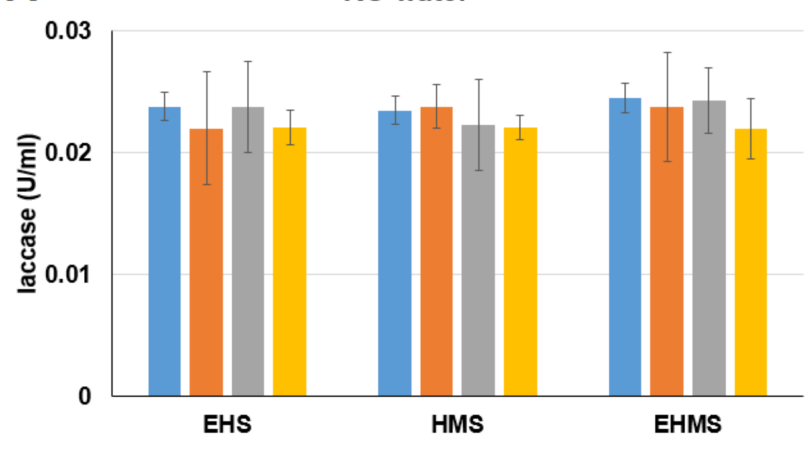

=30 mins Day $0=30$ mins Day $8 \approx 2 \mathrm{hrs}$ Day $0=2 \mathrm{hrs}$ Day 8

C

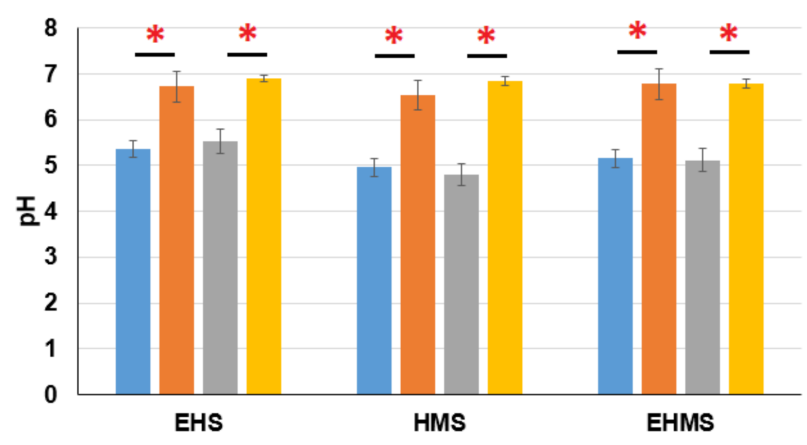

$=30$ mins Day $0 \approx 30$ mins Day $8 \approx 2$ hrs Day $0 \approx 2$ hrs Day 8

E

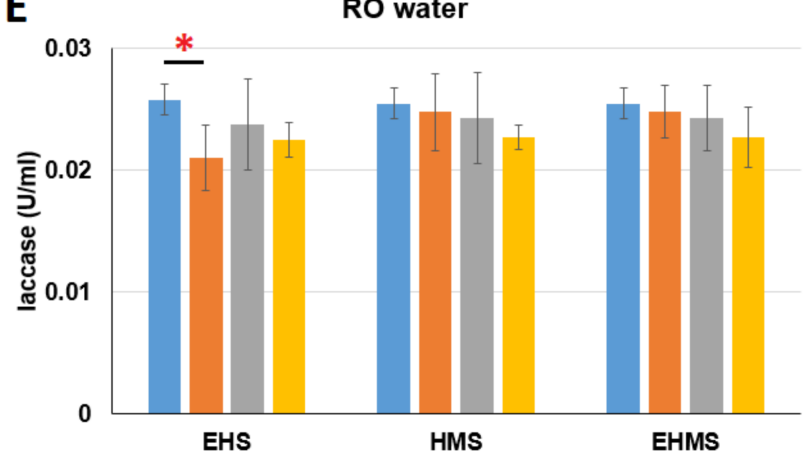

=30 mins Day $0 \approx 30$ mins Day $8 \approx 2$ hrs Day $0 \approx 2$ hrs Day 8

G

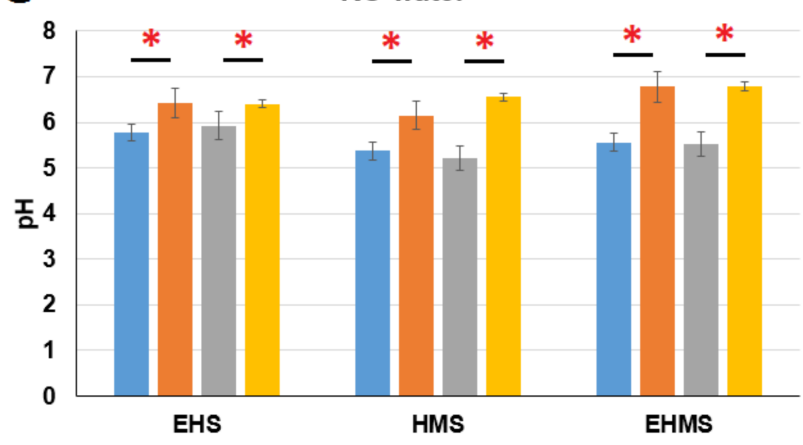

= 30 mins Day $0 \approx 30$ mins Day $8 \approx 2$ hrs Day $0 \approx 2$ hrs Day 8
B

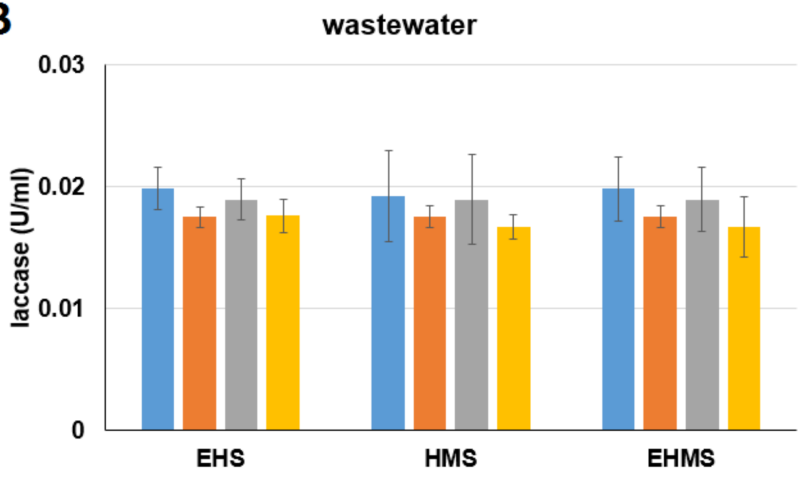

$\approx 30$ mins Day $0 \approx 30$ mins Day $8 \approx 2$ hrs Day $0 \approx 2$ hrs Day 8

D

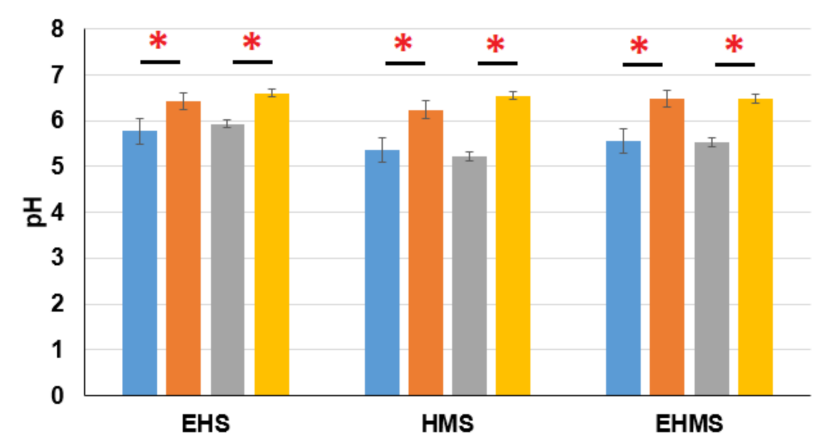

$\approx 30$ mins Day $0 \approx 30$ mins Day $8 \approx 2$ hrs Day $0 \approx 2$ hrs Day 8

F

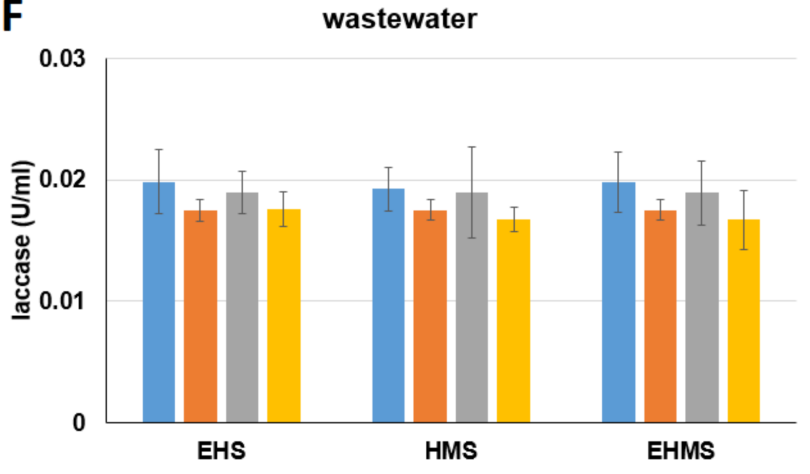

$=30$ mins Day $0 \approx 30$ mins Day $8 \approx 2$ hrs Day $0 \approx 2$ hrs Day 8

H

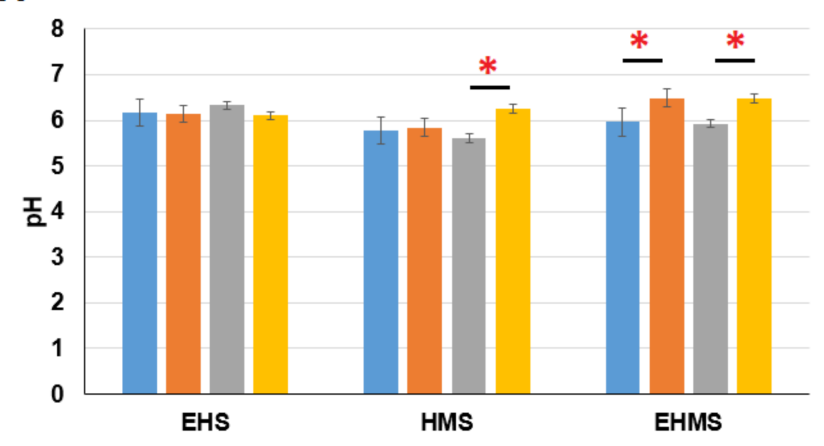

$\approx 30$ mins Day $0 \approx 30$ mins Day $8 \approx 2$ hrs Day $0 \approx 2$ hrs Day 8

Figure 9. Laccase activity and $\mathrm{pH}$ values of the enzyme extracts before (day 0 ) and after (day 8 ) the bioreactor experiments. Bioreactor experiments simulating UV filter removal in reverse osmosis (RO) filtration water and wastewater using the spent mushroom compost of two mushrooms (Pleurotus eryngii (A-D) and Pleurotus djamor (E-H)). Data from triplicate experiments are presented as the mean \pm SE. EHMC: ethylhexyl methoxycinnamate, EHS: 2-ethylhexyl salicylate, HMS: homosalate. Red stars indicate the $p$ values of $t$ tests $<0.05$. 
A

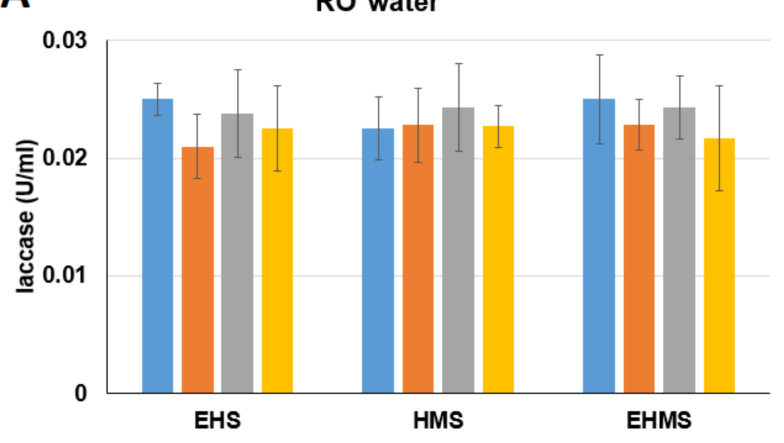

-30 mins Day $0=30$ mins Day $8=2$ hrs Day $0 \approx 2$ hrs Day 8

C

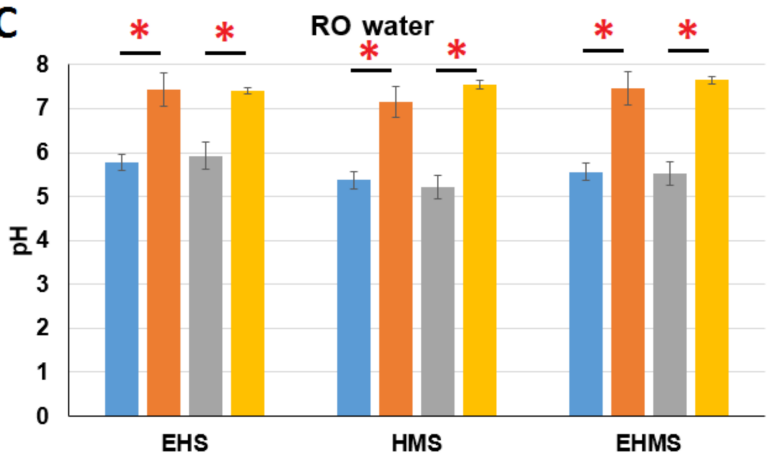

$\approx 30$ mins Day $0 \approx 30$ mins Day $8 \approx 2$ hrs Day $0 \approx 2$ hrs Day 8

E

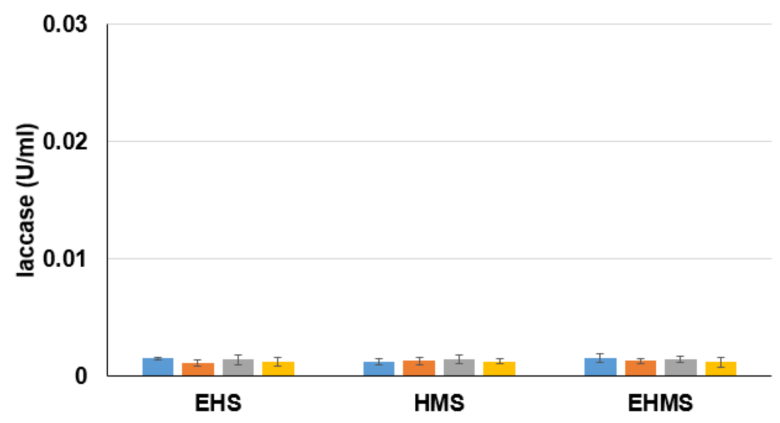

$\approx 30$ mins Day $0 \approx 30$ mins Day $8 \approx 2$ hrs Day $0 \approx 2$ hrs Day 8

G

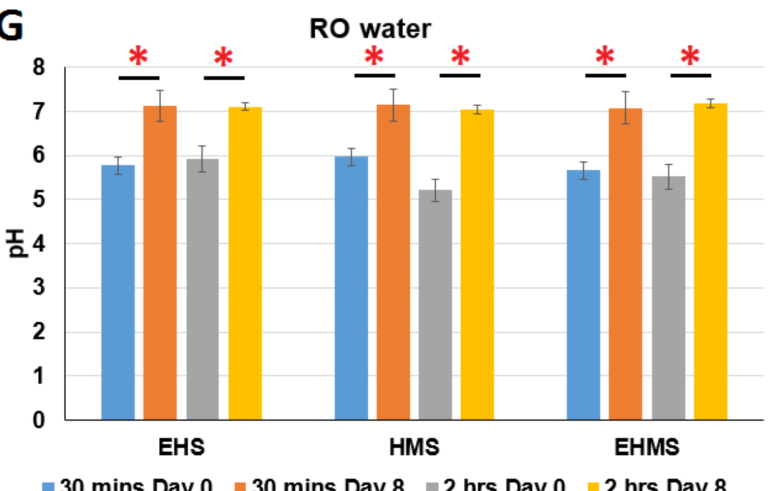

B

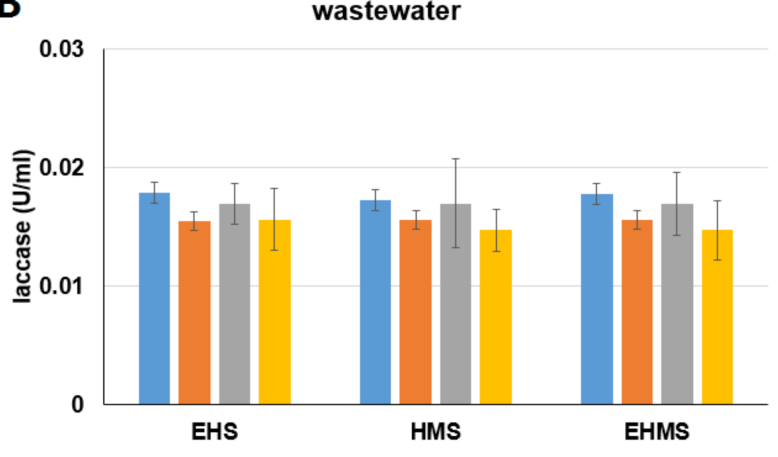

$\approx 30$ mins Day $0 \approx 30$ mins Day $8=2$ hrs Day $0 \approx 2$ hrs Day 8

D

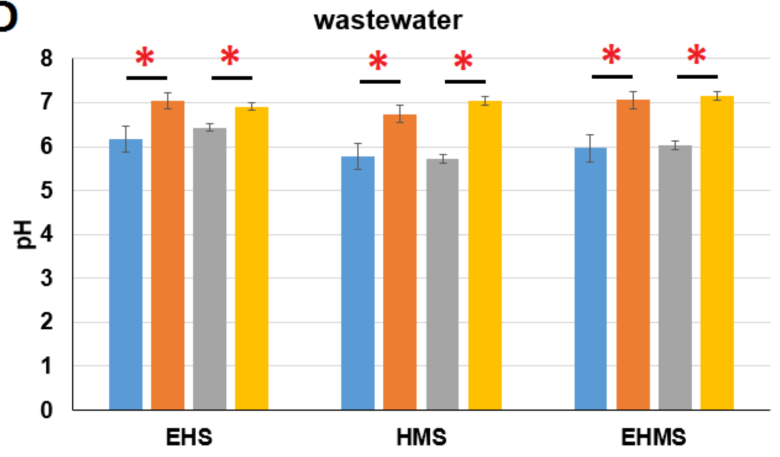

= 30 mins Day $0 \approx 30$ mins Day $8 \approx 2$ hrs Day $0 \approx 2$ hrs Day 8

$\mathbf{F}$

wastewater

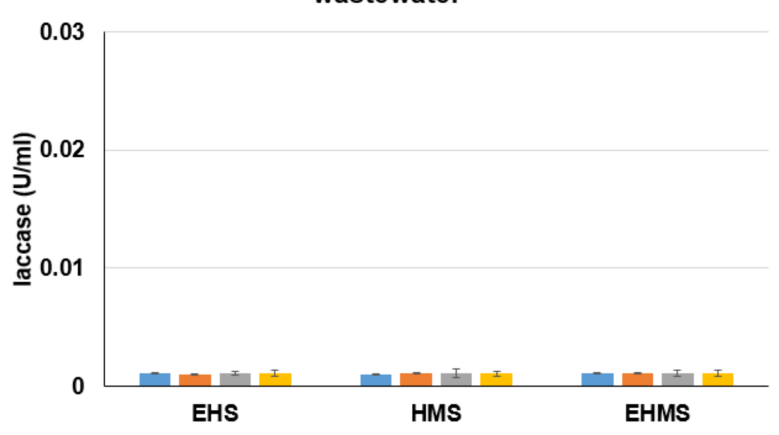

= 30 mins Day $0 \approx 30$ mins Day $8=2$ hrs Day $0=2$ hrs Day 8

H

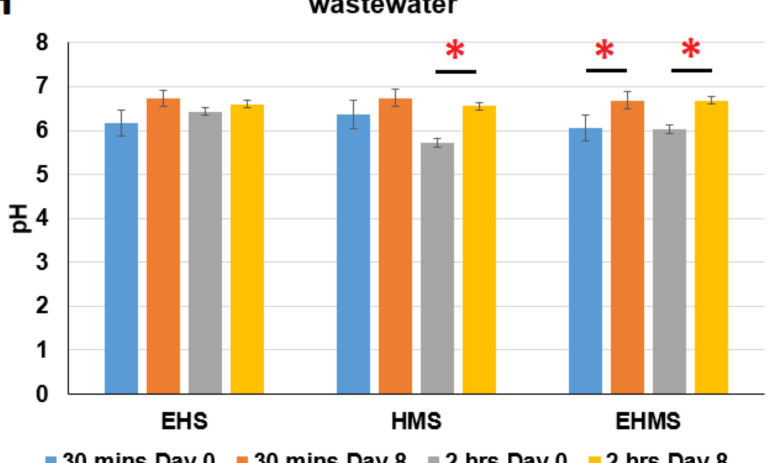

Figure 10. Laccase activity and $\mathrm{pH}$ values of the enzyme extracts before (Day 0 ) and after (Day 8) the bioreactor experiments. Bioreactor experiments simulating UV filter removal in reverse osmosis (RO) filtration water and wastewater using the spent mushroom compost of two mushrooms (Pleurotus ostreatus (A-D) and Auricularia polytricha (E-H)). Data from triplicate experiments are presented as the mean \pm SE. EHMC: ethylhexyl methoxycinnamate, EHS: 2-ethylhexyl salicylate, HMS: homosalate. Red stars indicate the $p$ values of $t$ tests $<0.05$. 


\section{Discussion}

Only a few intermediates were identified by GC/MS analysis. This may be due to the problem of sample collection, sample preparation and experimental technology. There are unknown reactions in the GC/MS results due to unidentified intermediates. Although the results shown in Figure 5 are incompletely hypothesized degradation pathways. However, these results indicate that EHS and HMS were degraded and EHMC was transformed by SMCs. More experiments need to be conducted to understand the detailed reaction mechanism of EHS and HMS biodegradation.

EHS and HMS were degraded into benzoic acid (Figure 5A,B) by the extracellular enzymes in the SMCs. He et al. (2020) indicated that benzoic acid can be degraded by the extracellular enzymes (lignin peroxidase and laccase) of the white-rot fungus Hypocrea lixii AH [28]. Zhao et al. (2020) indicated that 3-phenoxybenzoic acid can be degraded by Aspergillus oryzae M-4 [29]. A study by Xie et al. (2015) indicated that benzoic acid can be degraded by the endophytic fungus Phomopsis liquidambari [30]. Therefore, more investigations should be performed to ensure that the benzoic acid produced from EHS and HMS in this study can be further degraded by extracellular enzymes from P. djamor, P. ostreatus or P. eryngii.

The results in Figure 5 further support the proposal that the enzymes involved in the transformation of EHMC were different from the enzymes involved in the removal of EHS and HMS. The degradation of EHS and HMS may be associated with laccases because EHS and HMS were not degraded by enzyme extracts and SMCs of A. polytricha, which exhibit very low laccase activities (Figure 3D, Figure 4A, Figure 9E-H and Figure 10E,F) and evidenced by the study of Thakur et al. (2017) [31]. In contrast, EHMC was converted to an isomer (2-propenoic acid, 3-[4-methoxyphenyl]-, 2-ethylhexyl ester, Figure 5C). The isomerization of EHMC may have nothing to do with laccase because the reaction occurred in both enzyme extracts and SMCs of A. polytricha (Figure 3D, Figure 4A, Figure 9E-H and Figure 10E,F).

There are at least three factors that affect the adsorption of UV filters on SMCs. First, as shown in Figure 1, the chemical structures of EHS and HMS are similar and are different from that of EHMC. Therefore, EHS and HMS exhibit similar adsorption abilities for all four SMCs and exhibit different adsorption abilities from EHMC. Second, the differences in adsorption abilities of the four SMCs to one UV filter may be due to different compositions of SMCs for different fungi (Figure 6). Third, the rates of water or wastewater (containing UV filters) used to flow through the SMCs may cause differences; a slow flow rate $(500 \mathrm{~mL} / 2 \mathrm{~h}$ ) led to more UV filter adsorption on SMCs (Figures 7 and 9). These three factors should be considered in the real application of SMCs for wastewater treatments.

The direct application of SMCs for UV filter treatment is better than the use of enzyme extracts of SMCs and has three advantages. First, there are living fungal mycelia in SMCs that can continuously secrete extracellular enzymes to degrade the organic UV filters adsorbed onto the SMCs. Second, some of the extracellular enzymes were flushed out with wastewater (containing UV filters). Organic UV filters can be continuously degraded by these enzymes in the effluents. Third, the preparation of enzyme extracts of SMCs requires a large amount of water. In contrast, there is no extra requirement for water with the direct application of SMCs, which saves considerable time and costs.

\section{Conclusions}

In this study, SMCs, waste products of mushroom cultivation, were used as a lowcost material for the removal of emerging pollutants. This design not only employs the concept of mycoremediation but also turns SMCs into a useful resource. The P. djamor SMC exhibited the greatest effectiveness for EHS and HMS removal. Batch experiments suggested that laccases are associated with EHS and HMS degradation because EHS and HMS were not degraded by the SMC enzyme extracts of $A$. polytricha (with very low laccase activity). Another enzyme associated with EHMC biotransformation is present in 
all SMC enzyme extracts of the four mushrooms. Bioreactor experiments suggested that SMC could be used directly for UV filter removal from wastewater effluent. Although wastewater contains impurities that may inhibit laccase activities, the EHS and HMS removal in wastewater was comparable with the degradation efficiency of EHS and HMS in RO water. The mechanisms of SMCs for EHS and HMS removal include adsorption, biodegradation and biotransformation. The results of this study provide a feasible solution for the removal of two UV filters (EHS and HMS) from wastewater.

Author Contributions: Conceptualization, B.-V.C.; formal analysis, P.-H.T. and W.-Y.T.; methodology, P.-H.T. and W.-Y.T.; project administration, B.-V.C.; visualization, C.-W.Y.; writing-original draft preparation, C.-W.Y.; writing-review and editing, C.-W.Y. and B.-V.C. All authors have read and agreed to the published version of the manuscript.

Funding: This research was supported by the Ministry of Science and Technology, Taiwan (Grant Nos. MOST 109-2311-B-031-001- and MOST 109-2313-B-031-001-).

Institutional Review Board Statement: Not applicable.

Informed Consent Statement: Not applicable.

Conflicts of Interest: The authors declare no conflict of interest.

\section{References}

1. Sabzevari, N.; Qiblawi, S.; Norton, S.A.; Fivenson, D. Sunscreens: UV filters to protect us: Part 1: Changing regulations and choices for optimal sun protection. Int. J. Womens Dermatol. 2021, 7, 28-44. [CrossRef] [PubMed]

2. Huang, Y.; Law, J.C.; Zhao, Y.; Shi, H.; Zhang, Y.; Leung, K.S. Fate of UV filter Ethylhexyl methoxycinnamate in rat model and human urine: Metabolism, exposure and demographic associations. Sci. Total Environ. 2019, 686, 729-736. [CrossRef] [PubMed]

3. Yang, H.; Lu, G.; Yan, Z.; Liu, J.; Dong, H.; Bao, X.; Zhang, X.; Sun, Y. Residues, bioaccumulation, and trophic transfer of pharmaceuticals and personal care products in highly urbanized rivers affected by water diversion. J. Hazard Mater. 2020, $391,122245$. [CrossRef]

4. Ekpeghere, K.I.; Kim, U.J.; O, S.H.; Kim, H.Y.; Oh, J.E. Distribution and seasonal occurrence of UV filters in rivers and wastewater treatment plants in Korea. Sci. Total Environ. 2016, 542, 121-128. [CrossRef] [PubMed]

5. da Silva, C.P.; Emídio, E.S.; de Marchi, M.R. The occurrence of UV filters in natural and drinking water in São Paulo State (Brazil). Environ. Sci. Pollut. Res. Int. 2015, 22, 19706-19715. [CrossRef] [PubMed]

6. Kameda, Y.; Kimura, K.; Miyazaki, M. Occurrence and profiles of organic sun-blocking agents in surface waters and sediments in Japanese rivers and lakes. Environ. Pollut. 2011, 159, 1570-1576. [CrossRef] [PubMed]

7. Allinson, M.; Kameda, Y.; Kimura, K.; Allinson, G. Occurrence and assessment of the risk of ultraviolet filters and light stabilizers in Victorian estuaries. Environ. Sci. Pollut. Res. Int. 2018, 25, 12022-12033. [CrossRef] [PubMed]

8. He, K.; Hain, E.; Timm, A.; Tarnowski, M.; Blaney, L. Occurrence of antibiotics, estrogenic hormones, and UV-filters in water, sediment, and oyster tissue from the Chesapeake Bay. Sci. Total Environ. 2019, 650, 3101-3109. [CrossRef]

9. Krause, M.; Klit, A.; Blomberg Jensen, M.; Søeborg, T.; Frederiksen, H.; Schlumpf, M.; Lichtensteiger, W.; Skakkebaek, N.E.; Drzewiecki, K.T. Sunscreens: Are they beneficial for health? An overview of endocrine disrupting properties of UV-filters. Int. J. Androl. 2012, 35, 424-436. [CrossRef]

10. Downs, C.A.; Kramarsky-Winter, E.; Segal, R.; Fauth, J.; Knutson, S.; Bronstein, O.; Ciner, F.R.; Jeger, R.; Lichtenfeld, Y.; Woodley, C.M.; et al. Toxicopathological effects of the sunscreen UV filter, oxybenzone (benzophenone-3), on coral planulae and cultured primary cells and its environmental contamination in Hawaii and the U.S. Virgin Islands. Arch. Environ. Contam. Toxicol. 2016, 70, 265-288. [CrossRef]

11. Fivenson, D.; Sabzevari, N.; Qiblawi, S.; Blitz, J.; Norton, B.B.; Norton, S.A. Sunscreens: UV filters to protect us: Part 2-Increasing awareness of UV filters and their potential toxicities to us and our environment. Int. J. Womens Dermatol. 2020, 7, 45-69. [CrossRef]

12. Gago-Ferrero, P.; Díaz-Cruz, M.S.; Barceló, D. An overview of UV-absorbing compounds (organic UV filters) in aquatic biota. Anal. Bioanal. Chem. 2012, 404, 2597-2610. [CrossRef]

13. Huang, Y.; Law, J.C.; Lam, T.K.; Leung, K.S. Risks of organic UV filters: A review of environmental and human health concern studies. Sci. Total Environ. 2021, 755, 142486. [CrossRef]

14. Asgher, M.; Bhatti, H.N.; Ashraf, M.; Legge, R.L. Recent developments in biodegradation of industrial pollutants by white rot fungi and their enzyme system. Biodegradation 2008, 19, 771-777. [CrossRef]

15. Treu, R.; Falandysz, J. Mycoremediation of hydrocarbons with basidiomycetes-a review. J. Environ. Sci. Health B 2017, 52, 148-155. [CrossRef]

16. Zahmatkesh, M.; Spanjers, H.; van Lier, J.B. Fungal treatment of humic-rich industrial wastewater: Application of white rot fungi in remediation of food-processing wastewater. Environ. Technol. 2017, 38, 2752-2762. [CrossRef] 
17. Pozdnyakova, N.N. Involvement of the ligninolytic system of white-rot and litter-decomposing fungi in the degradation of polycyclic aromatic hydrocarbons. Biotechnol. Res. Int. 2012, 2012, 243217. [CrossRef]

18. Akhtar, N.; Mannan, M.A. Mycoremediation: Expunging environmental pollutants. Biotechnol. Rep. 2020, 26, e00452. [CrossRef]

19. Arregui, L.; Ayala, M.; Gómez-Gil, X.; Gutiérrez-Soto, G.; Hernández-Luna, C.E.; Herrera de Los Santos, M.; Levin, L.; Rojo-Domínguez, A.; Romero-Martínez, D.; Saparrat, M.C.N.; et al. Laccases: Structure, function, and potential application in water bioremediation. Microb. Cell Fact. 2019, 18, 200. [CrossRef]

20. Theerachat, M.; Guieysse, D.; Morel, S.; Remaud-Siméon, M.; Chulalaksananukul, W. Laccases from marine organisms and their applications in the biodegradation of toxic and environmental pollutants: A review. Appl. Biochem. Biotechnol. $2019,187,583-611$. [CrossRef]

21. Riva, S. Laccases: Blue enzymes for green chemistry. Trends. Biotechnol. 2006, 24, 219-226. [CrossRef] [PubMed]

22. Upadhyay, P.; Shrivastava, R.; Agrawal, P.K. Bioprospecting and biotechnological applications of fungal laccase. 3 Biotech 2016, 6, 15. [CrossRef] [PubMed]

23. Kumar, R.; Sharma, P.; Umar, A.; Kumar, R.; Singh, N.; Joshi, P.K.; A. Alharthi, F.; Ali Alghamdi, A.; Al-Zaqri, N. In vitro bioadsorption of $\mathrm{Cd}^{2+}$ ions: Adsorption isotherms, mechanism, and an insight to mycoremediation. Processes 2020, 8, 1085. [CrossRef]

24. Kapahi, M.; Sachdeva, S. Mycoremediation potential of Pleurotus species for heavy metals: A review. Bioresour. Bioprocess 2017, 4, 32. [CrossRef]

25. Chang, B.V.; Fan, S.N.; Tsai, Y.C.; Chung, Y.L.; Tu, P.X.; Yang, C.W. Removal of emerging contaminants using spent mushroom compost. Sci. Total Environ. 2018, 634, 922-933. [CrossRef]

26. Yang, C.W.; Tsai, L.L.; Chang, B.V. Fungi extracellular enzyme-containing microcapsules enhance degradation of sulfonamide antibiotics in mangrove sediments. Environ. Sci. Pollut. Res. 2018, 25, 10069-10079. [CrossRef]

27. Yang, C.W.; Chen, W.Z.; Chang, B.V. Biodegradation of tetrabromobisphenol-A in sludge with spent mushroom compost. Int. Biodeter. Biodeg. 2017, 119, 387-395. [CrossRef]

28. He, H.; Zhang, Q.; Tang, L.F.; Shi, K.Y.; Hong, F.F.; Tao, X.X.; Ali, M.I.; Urynowicz, M.; Huang, Z. Biodegradation of concentrated benzoic acid using white-rot fungus Hypocrea lixii AH. Environ. Eng. Sci. 2020, 37, 482-489. [CrossRef]

29. Zhao, J.; Jia, D.; Chi, Y.; Yao, K. Co-metabolic enzymes and pathways of 3-phenoxybenzoic acid degradation by Aspergillus oryzae M-4. Ecotoxicol. Environ. Saf. 2020, 189, 109953. [CrossRef]

30. Xie, X.G.; Dai, C.C. Biodegradation of a model allelochemical cinnamic acid by a novel endophytic fungus Phomopsis liquidambari. Int. Biodeterior. Biodegrad. 2015, 104, 498-507. [CrossRef]

31. Thakur, N.; Tripathi, A.; Sagar, S.; Kumar, P.; Devi, N.; Sharma, I.; Sharma, J. Estimation of extracellular ligninolytic enzymes from wild Auriculeria polytricha, Helvella sp. and Morchella sp. Int. J. Adv. Res. 2017, 5, 968-974. [CrossRef] 